\title{
OPEN Author Correction: Proteinaceous secretion of bioadhesive produced during crawling and settlement of Crassostrea gigas larvae
}

Valentin Foulon $\mathbb{D}^{\mathrm{D}}$, Sébastien Artigaud, Manon Buscaglia, Benoit Bernay, Caroline Fabioux $(\mathbb{D}$, Bruno Petton, Philippe Elies, Kada Boukerma, Claire Hellio, Fabienne Guérard \& Pierre Boudry

Correction to: Scientific Reports https://doi.org/10.1038/s41598-018-33720-4, published online 17 October 2018

A supplementary file containing Supplementary Video 1 was omitted from the original version of this Article. This has been corrected in the HTML version of the Article; the PDF version was correct at time of publication.

\begin{abstract}
(c) (i) Open Access This article is licensed under a Creative Commons Attribution 4.0 International License, which permits use, sharing, adaptation, distribution and reproduction in any medium or format, as long as you give appropriate credit to the original author(s) and the source, provide a link to the Creative Commons license, and indicate if changes were made. The images or other third party material in this article are included in the article's Creative Commons license, unless indicated otherwise in a credit line to the material. If material is not included in the article's Creative Commons license and your intended use is not permitted by statutory regulation or exceeds the permitted use, you will need to obtain permission directly from the copyright holder. To view a copy of this license, visit http://creativecommons.org/licenses/by/4.0/.
\end{abstract}

(C) The Author(s) 2020 